\title{
Pemodelan Pergerakan Pencemar Airtanah oleh Hidrokarbon di Kelurahan Jlagran Kota Yogyakarta
}

\author{
Harizona Aulia Rahman ${ }^{1 *}$, Doni Prakasa Eka Putra ${ }^{1}$, Heru Hendrayana $^{1}$ \\ ${ }^{1}$ Program Pascasarjana Teknik Geologi, Fakultas Teknik, Universitas Gadjah Mada, Indonesia
}

\begin{abstract}
Abstrak
Kebocoran tangki bahan bakar minyak untuk kereta api di Stasiun Tugu Yogyakarta pada tahun 1997 menyebabkan pencemaran airtanah pada sumur-sumur penduduk. Bahan bakar minyak (hidrokarbon) tergolong LNAPLs (Light Non Aqueous Phase Liquids), sukar larut dalam air. Penyebaran kontaminan (plume) pada airtanah dipengaruhi oleh biodegradasi. Penelitian terdahulu oleh Setyaningsih (2010) menyebutkan bahwa kecepatan aliran pada daerah penelitian adalah 1,5 km per tahun dalam kurun waktu 5 tahun, plume sudah mengalir jauh dari daerah penelitian. Berdasarkan informasi tersebut, sangat perlu diketahui arah pergerakan aliran airtanah dari 24 sumur observasi. Daerah penelitian merupakan bagian atas dari Sistem Akuifer Merapi (SAM) dengan penyusun endapan pasir dan endapan pasir krikilan, dengan aliran airtanah yang tidak seragam. Secara umum, aliran airtanah di daerah penelitian berarah utara-selatan. Di bagian selatan, aliran terpisah ke arah timur dan barat karena keberadaan sungai yang juga membatasi daerah penelitian.

Hasil pengukuran dan analisa sampel airtanah menunjukkan 13 sumur observasi diindikasikan tercemar oleh hidrokarbon dengan plume sepanjang $325 \mathrm{~m}$ bergerak dari barat laut ke tenggara. Simulasi penyebaran pencemar dan konsentrasi hidrokarbon terlarut dibuat pemodelan menggunakan BIOPLUME III. Nilai kandungan hidrokarbon yang dipakai diambil dari data sumur, yaitu $1 \mathrm{mg} / \mathrm{L}$ hingga $50 \mathrm{mg} / \mathrm{L}$.

Pergerakan plume di daerah penelitian mengikuti arah aliran airtanah dan diestimasi mengalami penurunan konsentrasi kemudian hilang setelah 54 tahun. Nilai konsentrasi berkurang dari $50 \mathrm{mg} / \mathrm{L}$ menjadi $1,63 \mathrm{mg} / \mathrm{L}$ dengan rata-rata penurunan konsentrasi sebesar 7,95 mg/L selama 10 tahun.
\end{abstract}

Kata kunci: Biodegradasi; BIOPLUME III; Jlagran Yogyakarta; pemodelan airtanah; plume.

\begin{abstract}
The train fuel tanks leakage at Tugu Station, Yogyakarta, in 1997 caused groundwater contamination in domestic wells around. The fuel is hydrocarbons that are categorized as LNAPLs (Light Non Aqueous Phase Liquids), pollutant that slowly dissolve into water. The groundwater contaminant movement is highly affected by biodegradation. Previous research by Setyaningsih (2010) mentioned that the flow rate at research area is $1,5 \mathrm{~km}$ per year within 5 years, and by now the plume must had been far away from its initial point. The groundwater flow direction is determined based on 24 observation wells. The research area is the upper part of the Merapi Aquifer System (MAS), composed of fine sand and coarse sand deposits, and has diverse groundwater flows. In general, the groundwater flow in research area has a north-south flow direction. At the southern part, the stream is split eastward and westward, that was caused by the presence of a river stream, which also act as the boundary of research area.

The groundwater measurements and samples indicate that 13 observation wells are indicated as contaminated and the plume is $325 \mathrm{~m}$ long, moving from northwest to southeast. The pollutant dispersion and the dissolved hydrocarbon simulation are determined through a model in BIOPLUME III.

The movement of plume in the research area is inline with groundwater flow direction and estimated to decrease in concentration and will disappear after 54 years. The concentration value decreased from $50 \mathrm{mg} / \mathrm{L}$ to $1,63 \mathrm{mg} / \mathrm{L}$ with an average concentration reduction of 7,95 $\mathrm{mg} / \mathrm{L}$ for 10 years.
\end{abstract}

Keywords : Biodegradation; BIOPLUME III; Jlagran Yogyakarta; groundwater modeling; plume.

*) Korespondensi: harizonarahman@gmail.com 


\section{PENDAHULUAN}

Airtanah merupakan sumber air yang sangat baik digunakan untuk kebutuhan manusia seharihari karena airtanah lebih aman dibandingkan dengan air permukaan. Namun, airtanah juga rentan terhadap pencemaran. Pencemaran terjadi akibat proses fisika, kimia ataupun biologi (Fried, 1975).

Pada tahun 1997 terjadi kebocoran tanki bahan bakar minyak kereta api di Stasiun Tugu, Yogyakarta, berdampak terhadap sistem airtanah di sekitar Stasiun Tugu hingga menyebabkan pencemaran airtanah yang masih dirasakan oleh masyarakat sekitar hingga saat ini. Putra (2007) menyebutkan bahwa beberapa sumur di daerah Jlagran tercemar oleh hidrokarbon berdasarkan kadar TOC (Total Organic Carbon) yang di atas batas normal. Model pencemaran dari Setyaningsih (2010) memiliki panjang kurang lebih $350 \mathrm{~m}$ dan lebar $270 \mathrm{~m}$. Wijaya (2015) menyatakan bahwa airtanah pada daerah Jlagran masih tercemar oleh hidrokarbon dan jarak pergerakan plume dari titik awal kontaminasi tidak jauh. Pergerakan plume mengarah ke Tenggara - Baratlaut dengan panjang plume $337,8 \mathrm{~m}$ dengan lebar 325m. Berdasarkan kondisi tersebut, diperlukan simulasi untuk menentukan konsentrasi hidrokarbon terlarut di bawah pengaruh biodegradasi dengan kandungan oksigen terbatas.

Penelitian ini bertujuan untuk mengetahui karakteristik hidrogeologi terutama aliran airtanah dangkal daerah penelitian. Selanjutnya menentukan pergerakan dan konsentrasi kontaminan, serta estimasi waktu pencemar hidrokarbon dalam airtanah hilang secara alami.

\section{Geologi Daerah Penelitian}

Dalam peta geologi lembar Yogyakarta (Rahardjo dkk., 1995), bagian baratdaya hingga selatan dan timur Yogyakarta merupakan dataran yang tertutup oleh endapan aluvium dari Gunung Merapi Muda. Setiadi (1990 dalam Putra, 2003) menyatakan bahwa Cekungan Merapi-Yogyakarta dibagi menjadi 6 zona geomorfologi, dengan daerah penelitian termasuk ke dalam morfologi lereng bawah Zona Gunungapi Merapi. Morfologi dibatasi oleh Selokan Mataram pada bagian utara dengan batas garis elevasi $150 \mathrm{~m}$.

Struktur geologi yang terbentuk antara lain lipatan dengan sumbu lipatan berarah timurlaut hingga baratdaya dan juga sesar. Data geofisika menyebutkan keberadaan sesar utama dengan arah timurlaut hingga baratdaya melalui tepi terban Bantul, kemudian diintegrasikan dengan data lapangan sehingga dapat ditentukan dua sistem sesar. Sistem sesar utama dengan arah baratdaya-timurlaut dan sistem kedua dengan arah kurang lebih tenggara-baratdaya.

Satuan penyusun daerah penelitian adalah Endapan Vulkanik Merapi Muda (Qmi). Satuan ini tersusun dari endapan tuff, abu, breksi, aglomerat, dan leleran lava tak terpisahkan. MacDonald dan Partners (1984 dalam Putra, 2003) menyatakan formasi Gunung Merapi Muda dibagi menjadi Formasi Sleman dan Formasi Yogyakarta membentuk sistem Akuifer Merapi.

\section{Geometri Akuifer}

Sistem aliran airtanah di Yogyakarta termasuk daerah penelitian merupakan bagian dari sistem Akuifer Merapi yang merupakan bagian dari graben yang kemudian terisi oleh endapan sungai dan endapan vulkaniklasik berumur kuarter sebagai hasil erupsi Gunung Merapi (Putra, 2007).

Formasi Yogyakarta merupakan bagian atas dari Sistem Akuifer Merapi (SAM) dengan ketebalan berkisar antara $10 \mathrm{~m}$ hingga $25 \mathrm{~m}$ dari permukaan. Material penyusun Formasi Yogyakarta adalah pasir dan kerikil. (MacDonald dan Partners, 1984; Putra, 2007; Wijaya 2015).

\section{Karakteristik Akuifer}

Konduktivitas hidrolika dari Sistem Akuifer Merapi berkisar antara 0,8 m/detik sampai 95,0 $\mathrm{m} /$ detik dengan nilai rata-rata adalah $8,6 \mathrm{~m} /$ detik dan nilai storativitasnya berkisar antara 0,001 hingga 0,25 (Putra, 2007). Berdasarkan nilai konduktivitas hidrolika dan storativitasnya dapat dikatakan bahwa Sistem Akuifer Merapi merupakan akuifer bebas hingga akuifer semi tertekan yang tergolong produktif.

Karakteristik akuifer lainnya yaitu nilai transmisivitas airtanah dari Sistem Akuifer Merapi berkisar antara $70 \mathrm{~m}^{2} /$ detik hingga 1650 $\mathrm{m}^{2} /$ detik dengan nilai rata-rata transmisivitasnya adalah $624 \mathrm{~m}^{2} /$ detik. Nilai permeabilitas rata-rata dari akuifer nya adalah $72,8 \mathrm{~m} /$ detik (MacDonald dan Partners, 1984). 


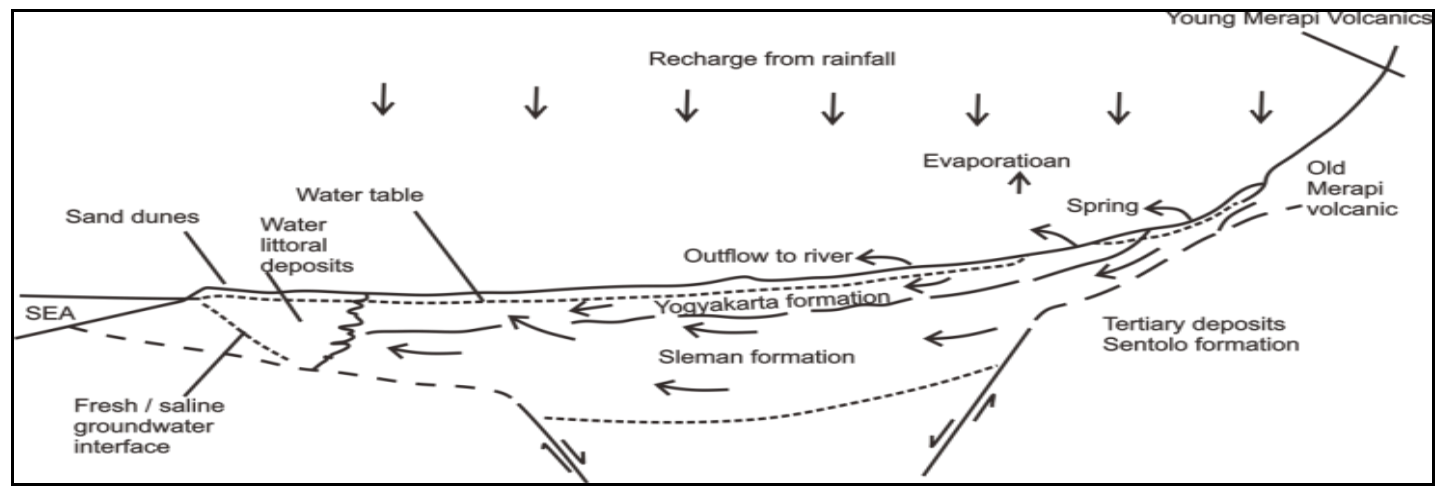

Gambar 1. Sayatan yang memotong graben Yogyakarta (MacDonald dan Partners, 1984 dengan modifikasi)

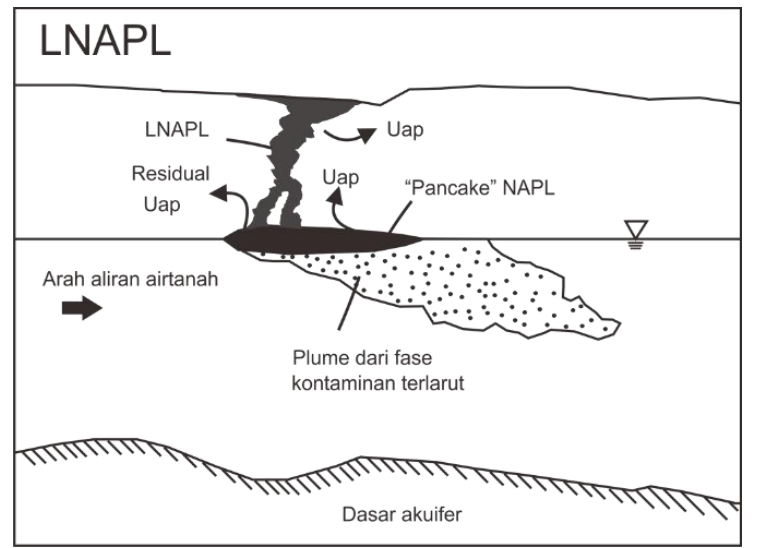

Gambar 2. Light Non-Aqueous Phase Liquids (Mackay dan Cherry, 1989 dengan modifikasi)

\section{Pencemaran Bahan Kimia Organik}

Bahan kimia organik merupakan bahan kimia yang didominasi oleh atom $\mathrm{C}$ dan $\mathrm{H}$. Salah satu jenis bahan kimia organik adalah Aromatic (pure) Hydrocarbon (BTEX). Petroleum Hidrokarbon dan turunannya tersusun oleh hidrogen dan karbon yang merupakan hasil dari minyak mentah, gas alam, dan batubara. Fuel (bahan bakar) merupakan hasil distilasi dari minyak mentah yang terbagi menjadi sejumlah fraksi berdasarkan titik didihnya (Domenico dan Schwartz, 1998).

Bahan kimia organik yang tergolong ke dalam LNAPLs adalah senyawa aromatik BTEX (benzene, toluene, ethyl-benzene, dan xylenes) dan termasuk di dalamnya adalah bahan bakar serta senyawa alifatik alkana yaitu oktana dan dekana (Bedient dkk., 1999). LNAPLs merupakan fase cair dari pencemar yang tidak dapat larut didalam air dimana fase ini memiliki densitas lebih rendah jika dibandingkan dengan densitas air (Bedient dkk., 1999)

Adanya proses atenuasi alami oleh airtanah merupakan suatu upaya untuk mereduksi konsentrasi pencemar. Proses atenuasi alami pada dasarnya merupakan proses pengurangan konsentrasi kontaminan. Salah satu dari proses atenuasi adalah proses biodegradasi. Prinsip dari biodegradasi adalah pemecahan molekul pencemar menjadi struktur molekul yang lebih sederhana sehingga memiliki tingkat toksisitas yang lebih rendah dan kemudian dapat diterima oleh lingkungan. Proses biodegradasi menyebabkan degradasi pencemar hidrokarbon yang bersifat racun menjadi asam organik dengan struktur molekul yang lebih sederhana sehingga risiko terhadap kesehatan yang lebih rendah (Morris dkk., 2003).

\section{METODOLOGI}

\section{Pengambilan Data Sumur}

Pengukuran data hidrogeologi dari 24 sumur meliputi ketinggian muka airtanah dan sampel airtanah. Titik sumur observasi di Kelurahan Jlagran dapat dilihat pada Gambar 3. Kontaminan diidentifikasi dari kenampakan fisik, yaitu warna dan bau, setelah sampel airtanah diistirahatkan selama 24 jam.

\section{Pemodelan Airtanah}

Data berupa karakteristik akuifer airtanah (hidrolika, konduktivitas, storage, densitas, densitas, dan dispersivity) yang dipakai untuk dapat membangun model menggunakan BIOPLUME III diperoleh dari penelitianpenelitian terdahulu (Tabel 1). Pemodelan dilakukan pada zona jenuh air dengan menambahkan parameter biodegradasi dengan kondisi aliran steady state, yaitu kondisi aliran airtanah tidak berubah terhadap waktu, dan kontaminan hidrokarbon yang stabil.

Kontaminan hidrokarbon sendiri memiliki densitas yang lebih rendah daripada air, sehingga akan terakumulasi di bagian atas airtahanah. Oleh karena itu, model yang dibuat 
tidak memerlukan parameter ketebalan akuifer. Selanjutnya, dijalankan simulasi pergerakan kontaminan hidrokarbon dalam kurun waktu 100 tahun pada model tersebut untuk dapat mengetahui estimasi waktu yang diperlukan dalam penurunan konsentrasi pencemar akibat proses biodegradasi.

\section{HASIL}

Peta kontur ketinggian muka airtanah (Gambar 4) dibuat dari hasil pengukuran yang dapat dilihat pada Tabel 2. Pada peta tersebut dapat teramati secara umum aliran airtanah memiliki arah aliran utara-selatan, yang kemudian pada bagian selatan dari daerah penelitian terpisah ke arah timur dan ke arah barat. Perubahan arah aliran airtanah tersebut dipengaruhi oleh keberadaan aliran sungai yang membatasi daerah penelitian. Di bagian barat daerah penelitian dibatasi oleh Kali Winongo dan pada bagian timur dibatasi oleh Kali Code (Gambar 4).

\section{Peta Penyebaran Kontaminan}

Berdasarkan hasil identifikasi dari kondisi airtanah pada sumur observasi, kemudian dilakukan pengelompokkan kategori plume dari kondisi fisik airtanah serta dikorelasikan bedasarkan nilai uji lemak yang dilakukan oleh Wijaya (2015) yang mendapatkan nilai konsentrasi tertinggi dari daerah penelitian sebesar $50 \mathrm{mg} / \mathrm{L}$ dan nilai terendah sebesar $1 \mathrm{mg} / \mathrm{L}$. Klasifikasi berdasarkan konsentrasi kontaminan adalah sebagai berikut :

1. Plume kontaminan $>50 \mathrm{mg} / \mathrm{L}$

2. Plume kontaminan $20-50 \mathrm{mg} / \mathrm{L}$

3. Plume kontaminan $10-20 \mathrm{mg} / \mathrm{L}$

4. Plume kontaminan $2-10 \mathrm{mg} / \mathrm{L}$

5. Plume kontaminan $1-2 \mathrm{mg} / \mathrm{L}$

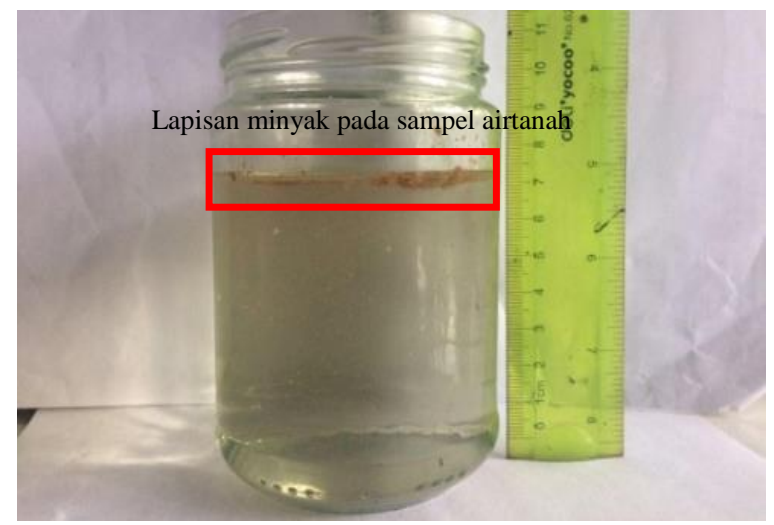

Gambar 3. Sampel airtanah pada SM-21 penelitian.
Tabel 1. Parameter untuk pemodelan

\begin{tabular}{lll}
\hline \multicolumn{1}{c}{ Input } & \multicolumn{1}{c}{ Nilai } & \multicolumn{1}{c}{ Sumber } \\
\hline Konduktivitas & $8,6 \mathrm{~m} / \mathrm{d}$. & Putra, 2007 \\
Storativitas & 0.2 & Putra, 2007 \\
Porositas & 0.35 & Fetter,1999 \\
Bulk Density & $1.18 \mathrm{~g} / \mathrm{cm}^{3}$ & Wijaya, 2015 \\
Dispersivitas & $0.16 \mathrm{~m}$ & $\begin{array}{l}\text { Spitz dan } \\
\text { Moreno, 1996 }\end{array}$ \\
\hline
\end{tabular}

Tabel 2. Identifikasi pencemaran pada sumur observasi

\begin{tabular}{|c|c|c|c|c|}
\hline \multirow[t]{2}{*}{ ID } & \multicolumn{2}{|c|}{ Koordinat Sumur } & \multirow{2}{*}{$\begin{array}{c}\text { Muka } \\
\text { Airtanah } \\
\text { (M) }\end{array}$} & \multirow{2}{*}{$\begin{array}{c}\text { Kondisi } \\
\text { Airtanah }\end{array}$} \\
\hline & $X$ & $\mathrm{Y}$ & & \\
\hline SM-1 & 429560 & 9138850 & 9.74 & Tercemar \\
\hline SM-2 & 429592 & 9138848 & 10.8 & Tercemar \\
\hline SM-3 & 429620 & 9138852 & 11.3 & Tercemar \\
\hline SM-4 & 429424 & 9138887 & 10.17 & Tercemar \\
\hline SM-5 & 429366 & 9138896 & 11.18 & Tercemar \\
\hline SM-6 & 429355 & 9138851 & 11.5 & Tercemar \\
\hline SM-7 & 429324 & 9138858 & 10.72 & Tercemar \\
\hline SM-8 & 429373 & 9138816 & 12.04 & Tercemar \\
\hline SM-9 & 429422 & 9138804 & 11.64 & Tercemar \\
\hline SM-10 & 429587 & 9138853 & 9.8 & $\begin{array}{c}\text { Sangat } \\
\text { Tercemar }\end{array}$ \\
\hline SM-11 & 429472 & 9138880 & 11.51 & Tercemar \\
\hline SM-12 & 429609 & 9138861 & 11.7 & Tercemar \\
\hline SM-13 & 429609 & 9139104 & 17.8 & $\begin{array}{c}\text { Tidak } \\
\text { Tercemar }\end{array}$ \\
\hline SM-14 & 430048 & 9138789 & 12.75 & $\begin{array}{c}\text { Tidak } \\
\text { Tercemar }\end{array}$ \\
\hline SM-15 & 429989 & 9139054 & 13.2 & $\begin{array}{c}\text { Tidak } \\
\text { Tercemar }\end{array}$ \\
\hline SM-16 & 429980 & 9138761 & 12.92 & $\begin{array}{c}\text { Tidak } \\
\text { Tercemar }\end{array}$ \\
\hline SM-17 & 430330 & 9138657 & 8.2 & $\begin{array}{c}\text { Tidak } \\
\text { Tercemar }\end{array}$ \\
\hline SM-18 & 430366 & 9138671 & 1.75 & $\begin{array}{c}\text { Tidak } \\
\text { Tercemar }\end{array}$ \\
\hline SM-19 & 429045 & 9138696 & 16.05 & $\begin{array}{c}\text { Tidak } \\
\text { Tercemar }\end{array}$ \\
\hline SM-20 & 429028 & 9138731 & 10.2 & $\begin{array}{c}\text { Tidak } \\
\text { Tercemar }\end{array}$ \\
\hline SM-21 & 429475 & 9138913 & 11.07 & $\begin{array}{c}\text { Sangat } \\
\text { Tercemar }\end{array}$ \\
\hline SM-22 & 429755 & 9138754 & 9.67 & $\begin{array}{c}\text { Tidak } \\
\text { Tercemar }\end{array}$ \\
\hline SM-23 & 429811 & 9138625 & 11.3 & $\begin{array}{c}\text { Tidak } \\
\text { Tercemar }\end{array}$ \\
\hline SM-24 & 429522 & 9138653 & 11.2 & $\begin{array}{c}\text { Tidak } \\
\text { Tercemar }\end{array}$ \\
\hline
\end{tabular}




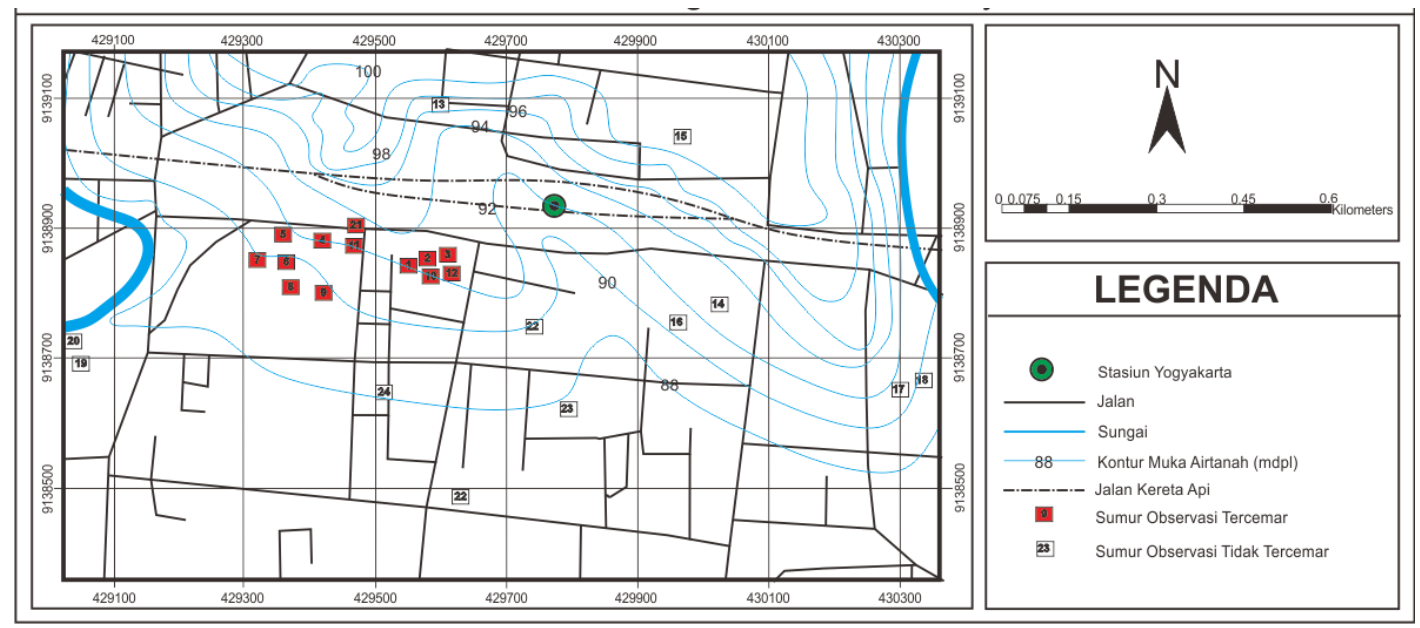

Gambar 4. Identifikasi Sumur Observasi

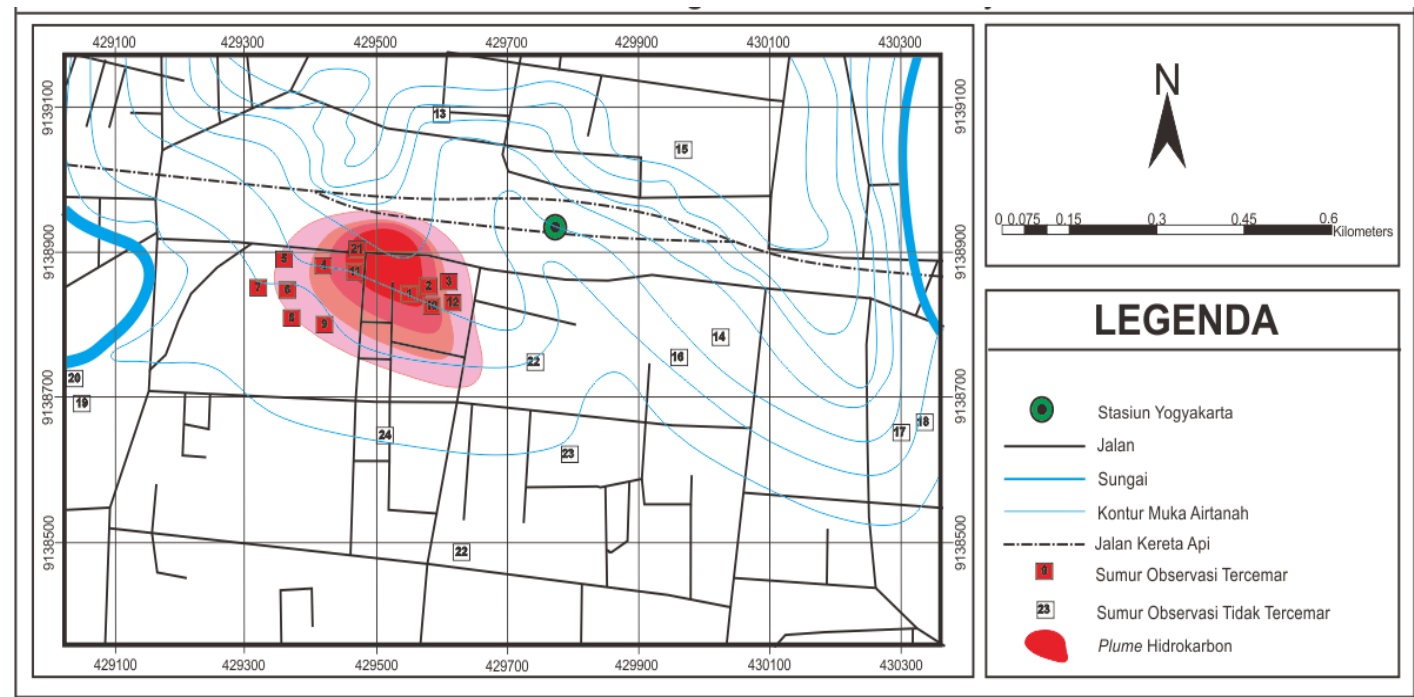

Gambar 5. Peta penyebaran plume hidrokarbon

Pada peta penyebaran plume yang dibuat dalam penelitian ini (Gambar 5), tampak pergerakan kontaminan yang relatif searah dengan arah aliran airtanah. Hal tersebut juga membuktikan bahwa pergerakan kontaminan dikontrol oleh sifat adveksi kontaminan. Nilai konsentrasi dari hidrokarbon mengalami penurunan dari $50 \mathrm{mg} / \mathrm{L}$ menjadi $1,63 \mathrm{mg} / \mathrm{L}$ seiring dengan penambahan jarak pergerakan plume disebabkan oleh kempampuan airtanah melakukan remediasi terhadap pencemar secara alami.

Dimensi plume yang terdapat pada daerah ini memiliki panjang $325 \mathrm{~m}$, terbentuk dari hasil pergerakan dari barat laut ke arah tenggara. Dimensi panjang plume ini relatif lebih kecil dibandingkan dari hasil penelitian terdahulu oleh Setyaningsih (2010) dan Wijaya (2015). Pada tahun 2010 pencemar memiliki panjang $350 \mathrm{~m}$ dan pada tahun 2015 pencemar memiliki panjang $337,8 \mathrm{~m}$. Plume semakin mengalami penyusutan dimensi seiring dengan penambahan waktu, sejak tahun 2010 hingga saat ini telah menyusut sepanjang $25 \mathrm{~m}$.

\section{Pemodelan Aliran Airtanah}

Pemodelan dibuat dengan asumsi tidak terjadi perubahan aliran airtanah, baik penurunan maupun kenaikan muka airtanah (steady state). Pencemar hidrokarbon yang merupakan LNAPLs termasuk pada jenis pencemar yang memiliki densitas lebih rendah jika dibandingkan dengan densitas air, sehingga pencemar terakumulasi mengambang diatas airtanah.

Berdasarkan asumsi tersebut ketebalan akuifer pada pemodelan tidak terlalu berpengaruh terhadap aliran pencemar. 


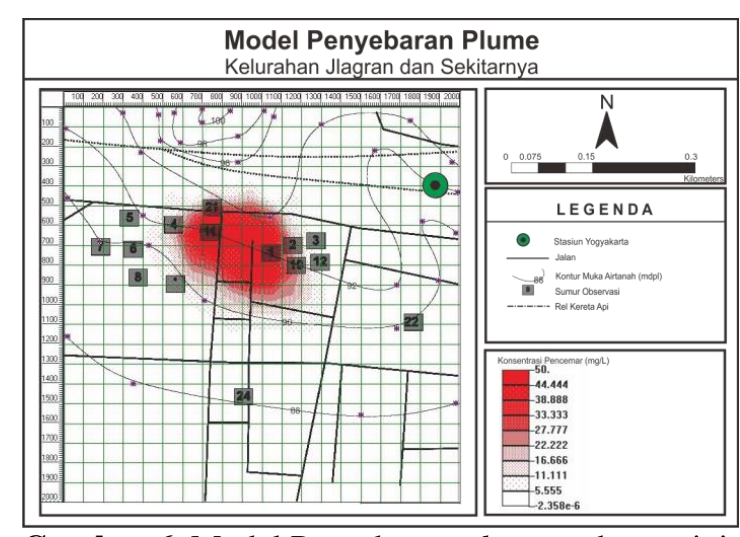

Gambar 6. Model Penyebaran plume pada saat ini.

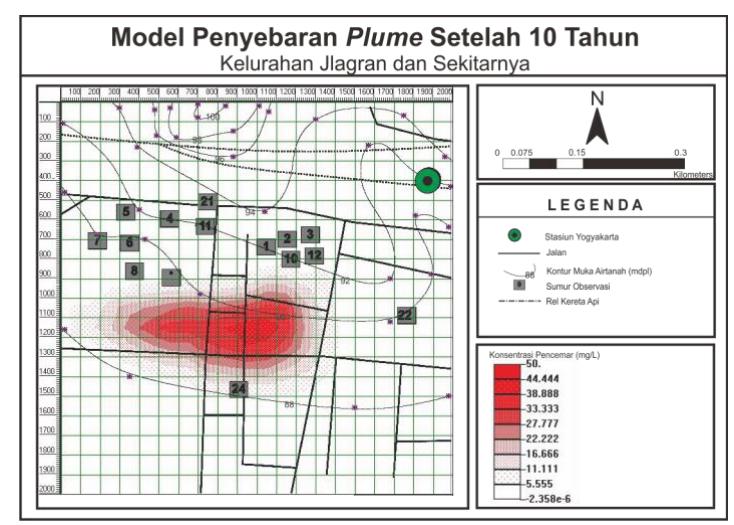

Gambar 7. Model penyebaran plume setelah 10 tahun.

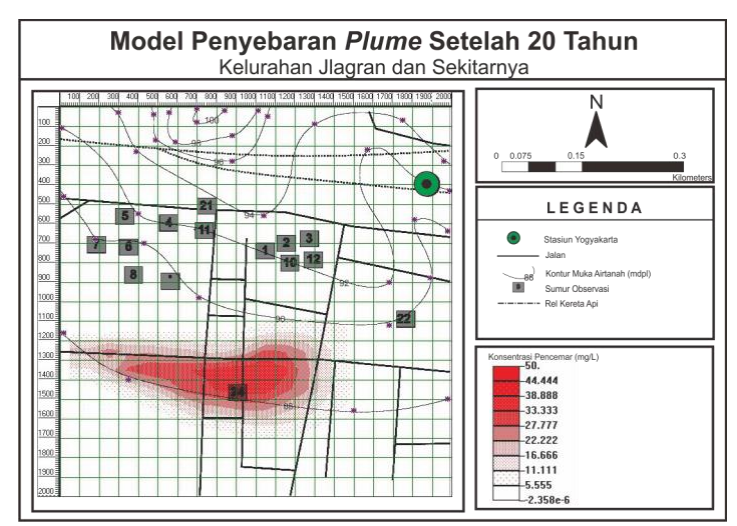

Gambar 8. Model penyebaran plume setelah 20 tahun.

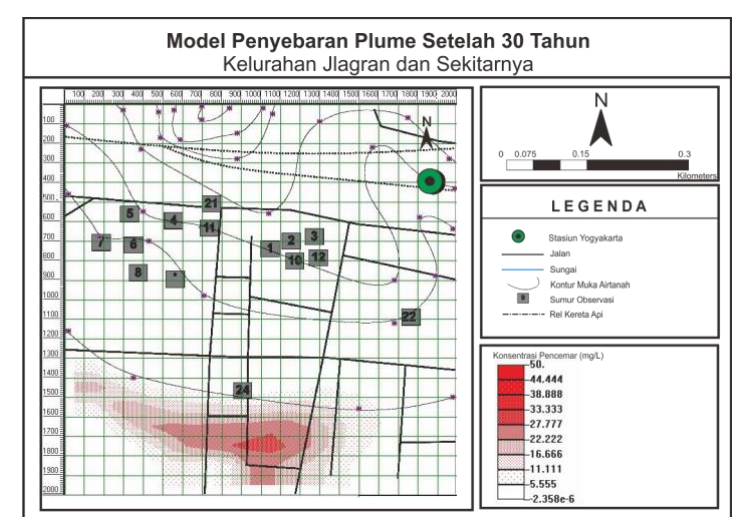

Gambar 9. Model penyebaran plume setelah 30 tahun.

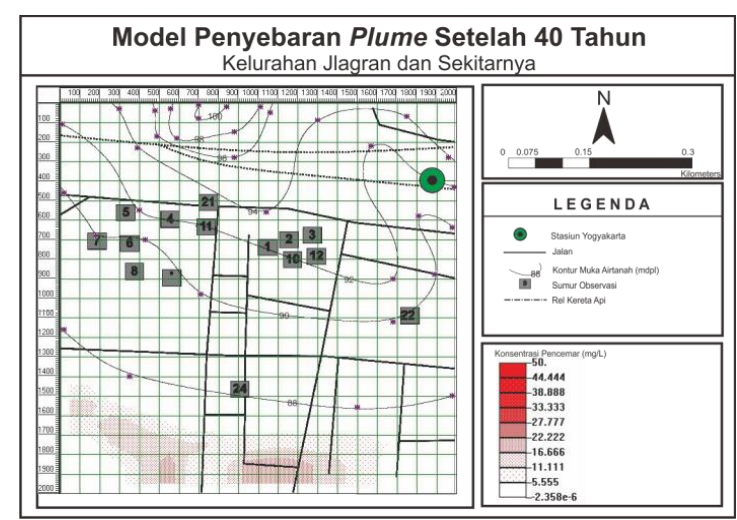

Gambar 10. Model penyebaran plume setelah 40 tahun

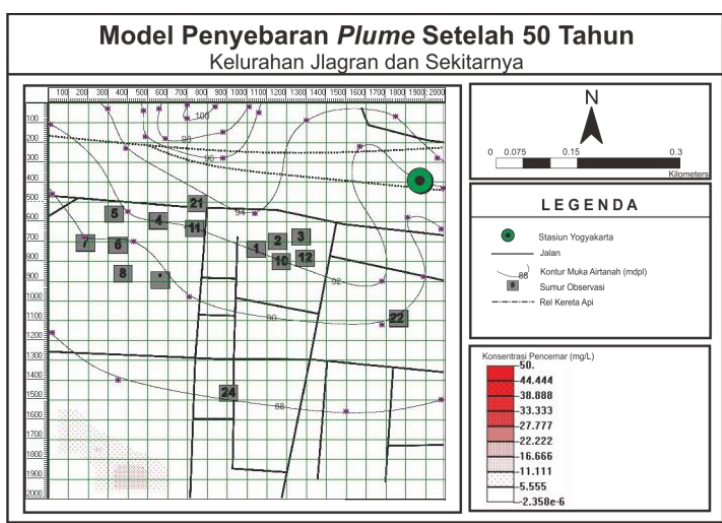

Gambar 11. Model penyebaran plume setelah 50 tahun.

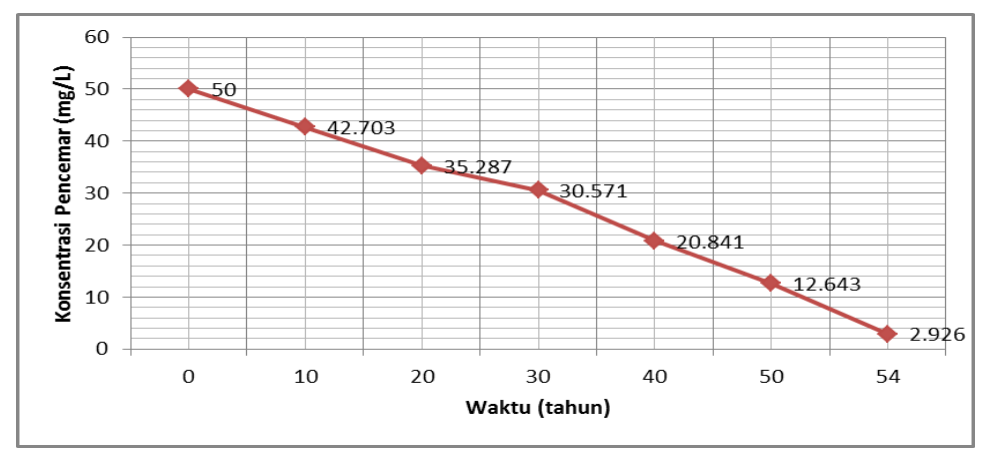

Gambar 12. Grafik penurunan nilai konsentrasi pencemar 
Pemodelan dari BIOPLUME III dilakukan berdasarkan kondisi plume daerah Jlagran saat ini, di mana pencemar hidrokarbon dinyatakan sudah berhenti (discontinuous).

\section{PEMBAHASAN}

\section{Hasil Pemodelan Pencemaran Hidrokarbon}

Berdasarkan Putra (2007) konsentrasi sulfat pada daerah penelitian adalah $76 \mathrm{mg} / \mathrm{L}$. Untuk simulasi ini diasumsikan bahwa konsentrasi asli dari oksigen terlarut dan sulfat dalam air tanah adalah $8 \mathrm{mg} / \mathrm{L}$ dan $80 \mathrm{mg} / \mathrm{L}$, sedangkan persamaan kimia umum untuk zat hidrokarbon adalah $\mathrm{C}_{7} \mathrm{H}_{8}$ (toluen). Pada kasus ini 9 volume molar dari oksigen diperlukan untuk mengkonversi $1 \mathrm{~mol}$ organik $\mathrm{C}_{7} \mathrm{H}_{8}$ (toluen) menjadi karbondioksida dan air. Reaksi BIOPLUME III diasumsikan berada pada massa per basis massa. Dengan konversi sebagai berikut:

$$
\begin{aligned}
\mathrm{C}_{7} \mathrm{H}_{8} & =92 \mathrm{~g} / \mathrm{mol} \text { Jadi, } 92 \mathrm{~g} / \mathrm{mol} \times 1 \mathrm{~mol} \\
& =92 \mathrm{~g} \\
\mathrm{O}_{2} & =32 \mathrm{~g} / \mathrm{mol} \mathrm{Jadi}, 32 \mathrm{~g} / \mathrm{mol} \times 9 \mathrm{~mol} \\
& =288 \mathrm{~g} \\
\text { Maka, } & 288 \mathrm{~g} / 92 \mathrm{~g}=3.1
\end{aligned}
$$

Berdasarkan konversi diatas, massa/rasio massa dari oksigen ke organik adalah $288 \mathrm{~g} / 92 \mathrm{~g}$ $=3,1$. Sehingga untuk kasus ini 3,1 g oksigen dibutuhkan untuk mengoksidasi $1 \mathrm{~g}$ hidrokarbon. Sedangkan untuk reduksi sulfat, mengasumsikan produksi hidrogen sulfida $\left(\mathrm{H}_{2} \mathrm{~S}\right)$ :

$\mathrm{C}_{7} \mathrm{H}_{8}+3,67 \mathrm{SO}_{4} \rightarrow 7 \mathrm{CO}_{2}+3,67 \mathrm{H}_{2} \mathrm{~S}+0.03$ $\mathrm{H}_{2} \mathrm{O}$

Pada konversi ini, 3,67 mol $\mathrm{SO}_{4}$ dibutuhkan untuk mengoksidasi $1 \mathrm{~mol} \mathrm{C}_{7} \mathrm{H}_{8}$ menghasilkan $3,8 \mathrm{mg} / \mathrm{L}$ sulfat yang diperlukan untuk mengoksidasi $1 \mathrm{mg} / \mathrm{L}$ toluen.

Berdasarkan proses tersebut maka diperoleh hasil bahwa kondisi plume yang terdapat pada lokasi penilitian menunjukkan perubahan aliran dari plume yang mengikuti arah aliran airtanah dimana. Pada awalnya aliran secara umum mengalir dari utara ke arah selatan yang kemudian pada bagian selatan daerah penelitian plume menyebar ke arah barat dan timur mengikuti aliran airtanah. Selain itu, pergerakan dari plume diikuti oleh proses penurunan konsentrasi pencemar yang diestimasi berlangsung dalam kurun waktu kurang lebih 54 tahun hingga pencemar hilang dari daerah Jlagran dan sekitarnya. Berdasarkan penyebaran pencemar dapat diketahui bahwa tingkat toksisitas mengalami penurunan dari $50 \mathrm{mg} / \mathrm{L}$ menjadi $1,63 \mathrm{mg} / \mathrm{L}$. Dari hasil pemodelan dapat diketahui tingkat penurunan dari konsentrasi pencemar setiap 10 tahun yang perubahannya ditunjukkan pada Gambar 6-11.

Grafik tingkat penurunan konsentrasi pencemar (Gambar 12) menunjukkan nilai pencemar tertinggi pada masing-masing model. Berdasarkan grafik penurunan konsentrasi pencemar diambil nilai rata-rata dari penurunan konsentrasi pencemar yang terdapat pada plume hidrokarbon. Dalam kurun waktu 54 tahun akan berlangsung penurunan konsentrasi rata-rata sebesar 7,95 mg/L per 10 tahun. Perhitungan tersebut menunjukkan bahwa pencemar membutuhkan waktu yang sangat lama untuk proses reduksi dari konsentrasi pencemar yang ada.

\section{KESIMPULAN}

Daerah penelitian disusun oleh litologi berupa endapan pasir dan endapan pasir krikilan. Secara umum aliran dari airtanah pada daerah penelitian memiliki arah aliran utara-selatan, yang kemudian pada bagian selatan dari daerah penelitian aliran tersebut terpecah ke arah timur dan ke arah barat yang dipengaruhi oleh adanya sungai yang membatasi daerah penelitian.

Plume memiliki dimensi panjang $325 \mathrm{~m}$ pada saat pengambilan sampel dilakukan, bergerak dari barat laut ke arah tenggara sesuai dengan pola aliran airtanah diikuti dengan penurunan konsentrasi dari plume melalui proses atenuasi alami oleh airtanah dari $50 \mathrm{mg} / \mathrm{L}$ menjadi 1.63 $\mathrm{mg} / \mathrm{L}$. Penurunan konsentrasi dari plume berlangsung selama 54 tahun hingga pencemar hilang dari daerah Jlagran dan sekitarnya. Penurunan konsentrasi pencemar rata-rata sebesar 7,95 mg/L dalam waktu 10 Tahun

\section{UCAPAN TERIMA KASIH}

Penulis bermaksud mengucapkan terima kasih kepada pihak-pihak yang membantu penulis selama pengambilan sampel di lapangan.

\section{DAFTAR PUSTAKA}

Bedient, P. B., Holder, A. W., Enfield, C. G., Wood, A. L., 1999. Enhanced Remediation Demonstration at Hill Air Force Base: 
Introduction. American Chemical Society Symposium Series, Vol. 725, hal. 36-48.

Domenico, P. A, dan Schtwartz, F. W., 1998. Physical and Chemical Hydrogeology. John Wiley \& Sons, Inc., USA

Fetter, C.W., 1999, Contaminant Hydrogeology, Waveland Press, Inc.: Illinois

Fried, J. J., 1975. Groundwater Pollution, Elsevier Scientific Publishing Company Amsterdam-Oxford: New York.

MacDonald, M. dan Partners, 1984, Greater Yogyakarta Groundwater Resources Study Volume 3 : Groundwater, Directorate general of Water Resources Develompent Project (P2AT), Ministry of Public Works, Government of The Republic of Indonesia.

Mackay, D. M. dan Cherry, J. A., 1989. Groundwater contamination: pump-and-treat remediation. Environmental Science \& Technology, Vol. 23 (6), hal. 630-636. DOI: 10.1021/es00064a001

Morris, B. L., Lawrence, A. R. L., Chilton, P. J. C, Adams, B., Calow R. C. dan Klinck, B. A., 2003. Groundwater and its Susceptibility to Degradation: A Global Assesment of the Problem and Options for Management. Early Warning and Assesment Report Series, RS. 03-3. United Nations Environment Programme, Nairobi: Kenya.

Putra, D. P. E., 2003. Intergrated water resources management in MerapiYogyakarta Basin. Tidak dipublikasikan. Universitas Gadjah Mada: Yogyakarta.

Putra, D. P. E., 2007. The Impact of Urbanization on Groundwater Quality A Case Study in Yogyakarta City - Indonesia. Mitteilungen zur Ingenieurgeologic und Hydrogeologic: Aachen.

Rahardjo, W., Sukandarrumidi, dan Rosidi H. M. D. 1995. Peta Geologi Lembar Yogyakarta, Skala 1:100.000. Pusat Penelitian dan Pengembangan Geologi. Bandung

Setyaningsih, W., 2010. Model Pergerakan Bahan Pencemar Minyak Disel pada Akuifer Batupasir Formasi Volkanik Merapi Muda. Jurnal Geografi Vol. 7 (2).

Spitz, K. dan Moreno, J. 1996. A Practical Guide to Groundwater and Solute Transport Modelling. John Wiley \& Sons, Inc.: New York.

Wijaya, S. Y., 2015. Pencemaran Airtanah oleh Bahan Bakar Minyak di Kelurahan Jagran,
Kecamatan Gedongtengen, Kota Yogyakarta. Skripsi. Jurusan Teknik Geologi. Fakultas Teknik. Universitas Gadjah Mada: Yogyakarta. 